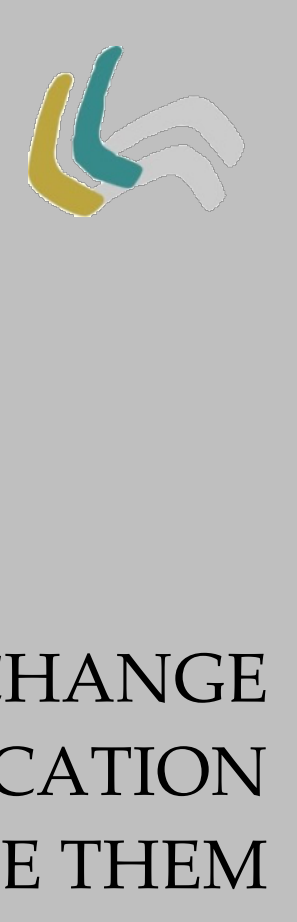

\title{
TWO OBSTACLES TO ENABLING CHANGE IN ELF-AWARE TEACHER EDUCATION AND HOW TO OVERCOME THEM
}

\author{
DOIS OBSTÁCULOS À MUDANÇA \\ NA EDUCAÇÃO DOCENTE VOLTADA PARA O ILF \\ E COMO SUPLANTÁ-LOS
}

\author{
Nicos C. Sifakis ${ }^{1}$ \\ Hellenic Open University
}

\begin{abstract}
In this paper I discuss the possibilities, opportunities, challenges and (even) perils in applying the ELF-aware perspective in teacher education. I focus on presenting two obstacles in enabling this application, the first related to teachers' attitudes, which tend to be fundamentally negative, and the second referring to an uncertainty about establishing, applying and evaluating appropriate ELF pedagogy. The obstacles are discussed with reference to examples from my personal experience as teacher educator, and argue (a) that these obstacles are also present in more "traditional" teaching and teacher education practices and (b) that they can be overcome if they are perceived as opportunities for integrating real-life interactions involving non-native English language users in the EFL classroom and prompting EFL teacher reflection and growth.
\end{abstract}

Keywords: ELF awareness, teacher education, teacher attitudes, ELF pedagogy.

1 sifakis@eap.gr 
Resumo: O meu objetivo neste artigo é discutir possibilidades, oportunidades e desafios e (até mesmo) perigos em se aplicar uma perspectiva voltada para o ELF na formação docente. Meu foco será apresentar dois obstáculos para implementar tal aplicação, fazendo referência a exemplos de minha experiência pessoal como formador de professores, e argumentar (a) que esses obstáculos estão presentes também tanto no ensino como na formação docente tidos como "tradicionais", e (b) que eles podem ser suplantados caso sejam percebidos como oportunidades para a integração de interações oriundas da vida real, envolvendo usuários não-nativos de língua inglesa na sala de Inglês como LE e articulando tanto a reflexão quanto o crescimento do professor que atua neste contexto (ILE).

Palavras-chave: Consciência sobre o ILF, Formação docente; atitude de professores; pedagogia de ILF

\section{INTRODUCTION}

There are many possible ways to look at the phenomenon of the global spread of English. One way is to describe the various uses of English around the world. Since the emphasis here is on "use", the primary instrument of research would be taken from discourse analysis and linguistics and would focus on both the observable, or so-called "surface" features of the language. These features would be primarily linguistic and functional, e.g., the grammar, the lexis, the pronunciation. However, to employ a useful term from the Chomskyan research toolbox, this type of analysis would only offer us an observational adequacy of the different uses of English, i.e., it would provide an exhaustive and discrete enumeration of the data. This is where the second level of analysis comes in, and this level refers to the underlying strategies and processes used by speakers of English during communication. This type of analysis also draws from discourse analysis but goes further into the sociolinguistics and pragmatics of communication and sheds light on the hidden and deeper (rather than the surface) elements of linguistic interaction, elements that help us understand the context of each interaction (e.g., the speakers involved, the topic, the setting, etc.) and perceive different interactions as being successful or unsuccessful.

ELF discourse analysis has gone through both of the two phases just described. Probably the best example of a predominantly linguistic analysis of "use" is Jenkins' Lingua Franca Core (JENKINS, 2000). Also, examples of predominantly sociolinguistic and pragmatic analyses of ELF discourse are to be found in Cogo and Dewey (2012) and elsewhere. Of particular interest are accounts of ELF discourse that merge the two perspectives, i.e. the linguistic and the socio-pragmatic, and attempt to give a more comprehensive overview of the 
"reality" of ELF interactions. This is the case, for example, with Grau's (2009) description of English used by young people in Germany; or with Jorgensen's (2008) account of the multiple languaging processes found in interactions involving English; or with Pitzl's (2018) account of different aspects of creativity in ELF interactions.

An altogether different, and much more complex, way of looking at the phenomenon of the global spread of English is to consider its implications for the language teaching classroom. Here the situation increases in complexity simply because of the many diverse parameters involved. One parameter refers to the contextual idiosyncrasies of the language classrooms around the world. Typically, and solely for the sake of simplicity, we tend to pitch ELF against the "traditional" EFL establishment. However, teaching contexts can vary significantly and, at times, even chaotically - primary-level education is different from secondary-level education, which is different from tertiary-level education, and all of these are different from contexts targeted at adult learners of different study styles and purposes. And, of course, even within teaching contexts, it is perfectly possible, even plausible and desirable, to apply the linguistic and discourse analytic tools mentioned earlier to establish the types of English used by teachers and learners in these contexts. Increasingly these days, the English used in the EFL classroom and the English used outside of it by the same users tends to be widely different (e.g., RANTA, 2010; papers in SIFAKIS; TSANTILA, 2019).

\section{THE EMERGENCE OF THE ELF AWARENESS PERSPECTIVE}

It is because of the complex nature of the links between the ELF construct itself, on the one hand, and the EFL classroom, on the other, that the term ELF awareness has been proposed (see SIFAKIS, 2014, 2019). The underlying assumption here is that linking ELF and EFL would be desirable on the following counts: that ELF represents real-life use of English by its non-native users around the world; that aspects of the EFL curriculum (e.g., teaching pronunciation) would be tailored to learners' realistic needs and wants (cf. the Lingua Franca Core proposed in JENKINS, 2000); that teaching that prioritises targeting the underlying communicational strategies over the surface discourse (see above) would prepare more effective users of English globally. That said, the question of the nature of the link between ELF and EFL remains open, although current 
opinion in teacher education seems to favour the "integrate-ELF-within-EFL" over the "replace-EFL-with-ELF" option (e.g., SIFAKIS ET AL, 2018 and papers in SIFAKIS; TSANTILA, 2019).

Despite these complexities, the ELF awareness perspective for teacher education and pedagogy views the EFL teacher as an autonomous practitioner who (a) is knowledgeable about ELF discourse analytic and socio-pragmatic research, (b) believes in the importance of integrating ELF within EFL, (c) is fully cognizant of the idiosyncrasies of their EFL teaching context (including the EFL curriculum and individual learner profiles), and (d) develops activities and tasks, or even entire lessons, that imbue their EFL instructional context with information and materials inspired from the so-called ELF construct. In other words, for ELF to be integrated within EFL, it is necessary that teachers are informed practitioners, in the best sense of the term "informed": they are familiar with the different instructional methods and approaches, they are fully cognizant and in control of their teaching context, and they are able to evaluate the effectiveness of their ELF-aware activities, tasks and lessons for their learners, inside that very specific teaching context.

Perceived this way, ELF awareness is a lot more than simply an awareness of ELF: it is essentially a form of EFL teacher development and empowerment (SIFAKIS, 2014). On the one hand, it does not offer specific solutions or tips for actually "teaching ELF", since, because of its inherent fluidity, ELF is not teachable (JENKINS ET AL, 2011). This means that, to date, there are no textbooks for teaching ELF, no dictionaries and no grammar books, only raw research published in academic journals and books. On the other hand, becoming ELF aware means learning as much as possible about your instructional context, the uses of English by your learners outside the EFL classroom, and realizing the limits of the EFL construct (often underlined by an adherence to native speaker norms and a negative washback from the established high-stakes examination culture-TSAGARI, 2009).

\section{TWO OBSTACLES TO ENABLING CHANGE IN ELF-AWARE TEACHER EDUCATION}

Essentially, ELF awareness is a form of teacher education that embraces change. And the need for change is probably the single most important element that scholars in applied linguistics and ESOL education agree upon: change from 
perceiving communication in terms of linguistic form to understanding it in terms of its fluidity and variability in different interactional contexts (Blommaert 2010); change in appreciating the huge impact that local uses of the language have not only on our understanding of English as a global language but also on the very processes of establishing norms (CANAGARAJAH, 2005; PENNYCOOK, 2007); change in "established ways of thinking $[\ldots]$ in the description and the teaching of English" (WIDDOWSON, 2012, p. 5); ultimately, change of teachers' "normative mindsets" (SEIDLHOFER, 2008, p. 33-34) and "more deeply rooted assumptions we hold about language" (PARK; WEE, 2011, p. 368).

In view of the above, however, I would like to argue in what follows that there are two fundamental obstacles to establishing change in ELF-aware teacher education. The first obstacle springs from teachers' attitudes, which tend to be fundamentally negative, while the second obstacle refers to an uncertainty about establishing, applying and evaluating appropriate ELF pedagogy. I will first present the obstacles and then suggest ways in which they may be overcome.

\section{FIRST OBSTACLE: TEACHER ATTITUDES}

Attitudes toward ELF have always been a central concern and a key research interest area in the published ELF research literature. There are good reasons for this, the primary one being that ELF deviates from established EFL norms. Such norms have been traditionally centered around the more prestigious Standard English varieties, predominantly British English and General American. While Standard English remains at the core of EFL teaching, applied linguists and sociolinguists agree that it is a product of decision-making that is ideologically burdened (BEX; WATTS, 1999, p. 39; PENNYCOOK, 2000, p. 119120). For example, it has been argued convincingly that Standard English in the UK is class-related, while in the USA it is race-related (cf. LIPPI-GREEN, 1997).

As already mentioned, the issue of attitudes has been widely documented in the ELF research literature. This is not the place to offer a detailed overview of such documentation (interested readers can consult JENKINS, 2007). However, it is important to make the following observation regarding EFL teachers' attitudes towards ELF.

It is widely documented that EFL teachers' attitudes towards ELF are predominantly negative (e.g. SIFAKIS; SOUGARI, 2005; for a review, see 
JENKINS, 2007). To understand this perspective, we need to look deeper at what EFL teachers do and at what they are. Typically, EFL teachers have strong convictions about what is 'correct' and 'appropriate' in language communication. This is especially true in countries of the Expanding Circle, where EFL teaching is largely dependent on inner-circle norms (MCKAY, 2003). Teacher's attitudes towards their instructional practice are heavily influenced by a number of parameters that need to be considered if changing them is at stake. One parameter is teachers' self-image and sense of professional obligations. These constraints spring from the curricular situations teachers find themselves in, the available courseware, the prevailing institutional and educational cultures and the established social-professional status teachers enjoy (SERCU, 2002; SIFAKIS, 2009).

There are further parameters that have been put forward, such as their personal history as learners (BEN-PERETZ ET AL, 2003), the way they have been educated by both their university studies and, during their in-service practice, by seminars that are sometimes designed by institutions that run high-stakes exams (STOBART, 2003). It is probably due to these deep convictions that many EFL teachers present a seemingly paradoxical perspective when asked about the importance of ELF in everyday interactions involving non-native speakers and its usefulness for their teaching practice: while they openly acknowledge the usefulness of the ELF-based skills, they tend to adopt a norm-bound, or Standard-English-biased perspective when asked specifically about language teaching (SIFAKIS; SOUGARI, 2005).

What can be done to counteract the negative teachers' attitudes towards ELF? First of all, it is necessary to make teachers tangibly aware of the reality of the role that English plays globally. Furthermore, in order to achieve this, what is needed is a rigorous teacher education programme that is centred around ELF awareness. The purpose of this training programme would not be to forcibly change teachers' perspectives, but to see ELF as an opportunity for prompting teachers to reflect on and get to know their own teaching context in all its glory and detail (as much as possible, of course).

Such a training programme would adopt the transformative framework laid out in the ELF awareness perspective (SIFAKIS, 2007, 2009, 2014, 2019). Teachers should be trained to see themselves as language users as well as teachers and reflect on the positive elements of their own communication skills, as users. For this to happen, they should become aware of their own ELF 
discourse (if they are non-native English language teachers). Then, teachers should reflect on the standards they hold dear concerning what they consider to be academic excellence in their practice. In other words, they should become aware of their own decisions as teachers in the EFL classroom, for example, with regard to correcting and providing feedback: when they do it and to what end they do it. Finally, they should become aware of their role as guardians or custodians of English not only for their learners but for the broader community. In other words, teachers should reflect on what they consider to be the characteristics of a successful teacher. More information on the design and implementation of such a programme can be found in Sifakis and Bayyurt (2015) and Bayyurt and Sifakis (2015a; 2015b).

\section{SECOND OBSTACLE: UNCERTAINTY ABOUT APPROPRIATE ELF PEDAGOGY}

Pedagogy lies at the epicentre of any perspective for the EFL classroom. The term "pedagogy" usually has a wide range of meanings that spans from perceptions about instructional philosophy to a comprehensive design for specific language learning activities and tasks. In any case, no one can deny that the predominant EFL framework offers specific responses and directives to the question about pedagogy, something which is far from true for the ELF construct.

It becomes evident from the above discussion that the EFL domain can be characterized as having two very distinct and rather contradictory features: while the orientation towards the language taught is rather simple and straightforward, in the sense that it prioritises, by definition, native speaker norms understood as "Standard English", the actual teaching contexts around the world can vary significantly, i.e., the ways in which EFL learners experience English around the world, as speakers or users of English, are extremely variable, fluid and unpredictable (JENKINS ET $A L, 2011$ ). For this reason, it is virtually impossible to design curricula that designate specifically the "type" of ELF to be "taught" in these contexts. Even if this were possible, different teaching contexts would incorporate very different "versions" of ELF, that would be dependable upon the uses of the language by the learners in each local context (cf. LOPRIORE; VETTOREL, 2019).

This obstacle essentially springs from a lack of certainty that most EFL teachers have about what would be required if ELF was to be integrated within 
their EFL practice. As EFL is quite firmly identified with Standard English and, more often than not, high-stakes exam practices, EFL contexts are more comprehensively furnished with a wide range of language learning courseware, exam preparation materials, dictionaries and grammar books (e.g., SIQUEIRA; MATOS, 2019). What is more, most EFL curricula are typically imbued with a substantial intercultural awareness component that incorporates the need for diversity from the Standard English norm "within reason". These perspectives are evident, for example, in the guidelines put forward in influential curricular materials such as the Common European Framework (in this regard, see PITZL's 2015 critique of the CEF). Further, these perspectives inform teacher education practices (cf. DEWEY; PATSKO's 2017 discussion of the attempt to modify the syllabus content of initial teaching awards in the UK).

If we consider the situation with ELF, the key driving force behind it seems to be the extremely widespread use of English by non-native speakers around the world. What ELF does not enjoy is a specific way of teaching it that is comprehensively supported by courseware, dictionaries, grammar books and teacher training practices. Most importantly, ELF does not orientate a specific instructional philosophy that is distinct from EFL. That said, broad frameworks for integrating ELF in the EFL classroom have been suggested. For example, Kirkpatrick has proposed that an "ELF approach" targets successful use of English in multilingual contexts by interculturally competent users (2012, p. 135). Similarly, Dewey (2012) and Blair (2015) outline the essentials of a "postnormative" pedagogical approach that prioritises a "post-native" model of learner multicompetence. Kohn suggests a "reconciliation between ELT and ELF" by putting forward a social constructivist ' "my English" conceptualization' (2015, p. 51).

What these proposals share is an understanding that, while learners can become aware of the discourse characteristics and other socio-pragmatic skills and strategies found in ELF interactions, ELF cannot be taught directly, at least not in the way in which EFL is taught, as "a monolithic version that should be taught in all contexts" (JENKINS ET AL, 2011, p. 305) Instead, the target of ELFaware instruction is to train learners into becoming skilled English users, through exposure to "insights into the heterogeneous nature of English as it is used in contact situations" (ibid.). In this sense, ELF should inform EFL teaching by empowering learners to avoid turning into "teachees" (i.e. passive recipients of 
what is taught) and grow into active participants in the learning process (SEIDLHOFER; WIDDOWSON, 2019).

For this to be achieved, it is necessary to prompt teachers to become autonomous practitioners, able to develop their own "eclectic methodology catering to a usage-based notion of multicompetence that involves bilingualism and biculturalism" (ALPTEKIN, 2010, p. 107). The so-called informed practitioner is, again, at the core of the solution to this obstacle. It is for this reason that we have time and again put forward a perspective for an "ELF-aware pedagogy" rather than an "ELF pedagogy". It is because of the fluidity of ELF and the need to focus on developing the skills required in participating in successful ELF interactions that we have argued against an "ELF-informed" pedagogy. What we are seeking is a pedagogy that is ELF-aware, in the sense that it goes beyond a mere awareness of the existence of ELF and extends towards a comprehensive understanding of the local EFL context, the learners involved, the ELF uses they engage in as ELF speakers outside the EFL classroom, the attitudes and convictions of every stakeholder involved (learners themselves, their parents or sponsors, the directors of study, etc.), and, of course, the curriculum and courseware selected. Different contexts will necessitate different approaches to the question of integrating ELF within EFL and will require a skillful and reflective practitioner able of inventing their own very specific instructional interventions, learning from these applications and improving upon them (see KORDIA's 2019 account of the implementation of the ELF aware instructional perspective in her own teaching context).

\section{CONCLUSION}

In this paper I have suggested that the road to integrating ELF within EFL is faced with two obstacles. The first obstacle springs from teachers' convictions about what is expected of them in their EFL contexts and their concomitant negative attitudes towards integrating ELF in their practices. The second obstacle refers to the lack of a comprehensive instructional framework for ELF, as opposed to the very comprehensive EFL pedagogical philosophy and practice.

I have suggested that both of these obstacles can be overcome through the ELF aware perspective. ELF awareness posits that, on one level, EFL teachers become tangibly aware of the ELF construct. This means that they understand the global use of English, and are able to comprehend ELF both at the surface 
level (discourse involving non-native speakers) and at the deeper level (skills and strategies employed during ELF interactions). On another level, ELF awareness implies that teachers become aware of their own attitudes towards the ELF construct and are prompted to reflect on issues such as the effectiveness and creativity of ELF interactions, the limitations of EFL, and the ownership of English vis-à-vis the roles of native and non-native users. On yet another level, EFL teachers are invited to reflect on their own teaching practices and their personal convictions about appropriate language teaching (including the role of feedback and their own correction principles and techniques). Furthermore, they are required to learn everything about their own teaching context, their learners' learning profiles and uses of English outside the EFL class, and develop, implement and evaluate tasks and activities that attempt to integrate ELF in this context.

As research in integrating ELF within EFL grows, it becomes evident that EFL teachers are requested to enter a transformative journey that will change their mindsets concerning what really works both in in-class sessions and in interactions outside the class. Essentially, as teacher educators we can begin to remove the problems and obstacles described in this paper by developing ELFaware teachers as informed practitioners and reflective and autonomous agents of change for their teaching context.

\section{REFERENCES}

ALPTEKIN, C. Redefining multicompetence for bilingualism and ELF. International Journal of Applied Linguistics, v. 20, n. 1, p. 95-110. 2010.

BAYYURT, Y.; N. C. SIFAKIS. Transforming into an ELF-aware teacher: an EFL teacher's reflective journey. In: BOWLES, H.; COGO, A. (Ed.), International perspectives on teaching English as a lingua franca: pedagogical insights. London: Palgrave MacMillan, 2015a. p. 117-135.

BAYYURT, Y.; SIFAKIS, N. Developing an ELF-aware pedagogy: insights from a selfeducation programme. In VETTOREL, P. (Ed.), New frontiers in teaching and learning English. London: Cambridge Scholars Publishing, 2015b. p. 55-76.

BEN-PERETZ, M.; MENDELSON, N.; FRIEDRICH, W. K. How teachers in different educational contexts view their roles. Teaching and Teacher Education. n. 19, p. 277-290. 2003. 
BEX, T.; WATTS, R. J. (Ed.) Standard English: the widening debate. London: Routledge, 1999.

BLAIR, A. Evolving a post-native, multilingual model for ELF-aware teacher education. In: BAYYURT, Y.; AKCAN, S. (Ed.). Current Perspectives on Pedagogy for ELF. Berlin: De Gruyter Mouton, 2015.

BLOMMAERT, J. The Sociolinguistics of Globalization. Cambridge: Cambridge University Press, 2010.

CANAGARAJAH, S. Reconstructing local knowledge, reconfiguring language studies. In CANAGARAJAH, S. (Ed.), Reclaiming the Local in Language Policy and Practice. London: Erlbaum, 2005, p. 3-24.

COGO, A.; DEWEY, M. Analysing English as a lingua franca. London: Continuum. 2012.

DEWEY, M. Towards a post-normative approach: learning the pedagogy of ELF. Journal of English as a Lingua Franca, v. 1, n. 1, p. 141-170, 2012.

DEWEY, M.; PATSKO, L. ELF and teacher education. In JENKINS, J.; BAKER, W.; DEWEY, M. (Ed.) The Routledge Handbook of English as a Lingua Franca. London; Routledge, 2017, p. 441-455.

GRAU, M. Worlds apart? English in German youth cultures and in educational settings. World Englishes, v. 28, n. 2, p. 160-174, 2009.

JENKINS, J. The phonology of English as an international language. Oxford: Oxford University Press. 2000.

JENKINS, J. English as a lingua franca: attitude and identity. Oxford: Oxford University Press. 2007.

JENKINS, J.; COGO, A.; DEWEY, M. Review of developments in research into English as a lingua franca. Language Teaching Research, v. 44, n. 3, p. 281-315, 2011.

JORGENSEN, J. N. Polylingual languaging around and among children and adolescents. International Journal of Multilingualism, v. 5, n.3, p. 161-176, 2008.

KIRKPATRICK, A. English as an Asian Lingua Franca: the "Lingua Franca Approach" and implications for language education policy. Journal of English as a Lingua Franca, v.1, n. 1, p. 121-140, 2012.

KOHN, K. A pedagogical space for ELF in the English classroom.' In BAYYURT, A.; AKCAN, S. (Ed.) Current Perspectives on Pedagogy for ELF. Berlin: De Gruyter Mouton, 2015. p. 51-67 
KORDIA, S. ELF-aware teaching in EFL classrooms: pedagogical and practical considerations. In SIFAKIS, N.; TSANTILA, N. (Ed.). English as a lingua franca for EFL contexts. Bristol: Multilingual Matters, 2019. p. 53-71.

LIPPI-GREEN, R. English with an accent: language, ideology, and discrimination in the United States. London: Routledge. 1997.

LOPRIORE, L.; VETTOREL, P. Perspectives in WE- and ELF-informed ELT materials in teacher education. In SIFAKIS, N. C.; TSANTILA, N. (Ed.). English as a lingua franca for EFL contexts. Bristol: Multilingual Matters, 2019. p. 97-116.

MCKAY, S. Teaching English as an international language: the Chilean context. ELT Journal, v. 57, n. 2, p. 139-48. 2003.

PARK, J. S.-Y.; WEE, L. A practice-based critique of English as a Lingua Franca.' World Englishes, v. 30, n. 3, p. 360-74. 2011.

PENNYCOOK, A. Disinventing standard English. English Language and Linguistics, v. 4, n. 1, p. 115-124. 2000.

PENNYCOOK, A. Global Englishes and Transcultural Flows. London: Routledge. 2007.

PITZL, M.-L. Understanding and misunderstanding in the Common European Framework of reference: what we can learn from research on BELF and intercultural communication. Journal of English as a Lingua Franca, v. 4, n. 1, p. 91-124. 2015.

PITZL, M.-L. Creativity in English as a lingua franca: idiom and metaphor. Boston: Mouton de Gruyter. 2018.

RANTA, E. English in the real world vs. English at school: Finnish English teachers' and students' views.' International Journal of Applied Linguistics, v. 20, n. 1, p. 156-77. 2010.

SEIDLHOFER, B. Of norms and mindsets. Australian Review of Applied Linguistics, v. 31, n. 3, p. 1-7. 2008.

SEIDLHOFER, B.; WIDDOWSON, H. ELF for EFL: a change of subject? In SIFAKIS, N. C.; TSANTILA, N. (Ed.) English as a lingua franca for EFL contexts. Bristol: Multilingual Matters, p. 17-31. 2019.

SERCU, L. Implementing intercultural foreign language education: Belgian, Danish and British teachers' professional self-concepts and teaching practices compared. Evaluation and Research in Education, v. 16, p. 150-165. 2002. 
SIFAKIS, N. C. The education of the teachers of English as a lingua franca: a transformative perspective. International Journal of Applied Linguistics, v. 17, n. 3, p. 355375. 2007.

SIFAKIS, N. C. Challenges in teaching ELF in the periphery: the Greek context. ELT Journal, v. 63, n. 3, p. 230-237. 2009.

SIFAKIS, N. C. ELF awareness as an opportunity for change: a transformative perspective for ESOL teacher education. Journal of English as a Lingua Franca, v. 3, n. 2, p. 317-335. 2014.

SIFAKIS, N. C. 2019. ELF awareness in English language teaching: principles and processes. Applied Linguistics, v. 40, n. 2, p. 288-306. 2019.

SIFAKIS, N. C.; BAYYURT, Y. Insights from ELF and WE in teacher training in Greece and Turkey. World Englishes, v. 34, n. 3, p. 471-484. 2015.

SIFAKIS, N. C.; LOPRIORE, L.; DEWEY, M.; BAYYURT, Y.; VETTOREL, P.;

CAVALHEIRO, L.; SIQUEIRA, S. P.; KORDIA S. ELF awareness in ELT: bringing together theory and practice. Journal of English as a Lingua Franca, v. 7, n. 1, p. 155-209. 2018.

SIFAKIS, N. C.; SOUGARI, A.-M. Pronunciation issues and EIL pedagogy in the periphery: a survey of Greek state school teachers' beliefs. TESOL Quarterly, v. 39, n. 3, p. 467-488. 2005.

SIFAKIS, N. C.; TSANTILA, N. (Ed.). English as a lingua franca for EFL contexts. Bristol: Multilingual Matters. 2019.

SIQUEIRA, S; MATOS, J. V. G. LT materials for basic education in Brazil: has the time for an ELF-aware practice arrived? In SIFAKIS, N. C.; TSANTILA, N. (Ed.). English as a lingua franca for EFL contexts. Bristol: Multilingual Matters, p. 132-158. 2019.

STOBART, G. The impact of assessment: Intended and unintended consequences. Assessment in Education: Principles, Policy and Practice, v. 16, p. 139-140. 2003.

TSAGARI, D. The complexity of test washback: An empirical study. Frankfurt am Main: Peter Lang GmbH. 2009.

WIDDOWSON, H. ELF and the inconvenience of established concepts. Journal of English as a Lingua Franca, v. 1, n. 1, p. 5-26. 2012. 


\section{Nicos Sifakis}

Nicos Sifakis is a full professor of English for specific purposes in the School of Humanities of the Hellenic Open University (HOU) and director of its M.Ed. in TESOL programme. He holds a Ph.D. in language and linguistics from the University of Essex, UK. He is editorin-chief of Research Papers in Language Teaching and Learning. He has published extensively on intercultural communication and pedagogy, language teaching methodology, distance education, adult education and teacher education. He is co-editor of ELF for EFL Contexts (Multilingual Matters, 2019), Using English as a Lingua Franca in Education in Europe (De Gruyter, 2018) and English Language Education Policies and Practices: A Mediterranean Perspective (Peter Lang, 2017). He is also coordinator of the Erasmus-funded research programme ENRICH. For more information and updates on his published research, see:

https://www.researchgate.net/profile/Nicos_Sifakis/publications.

Nota do editor: Artigo submetido para avaliação em: 20/03/2019. Aprovado em sistema duplo cego em: 02/11/2019. 